\title{
Synthetic routes proposed by a noninteractive synthesis program
}

\author{
Tetsuhiko Takabatake* \\ Takatsuki Research Laboratory, Sumitomo Chemical Co. Ltd., \\ 10-1-2-chome, Tsukahara, Takatsuki-shi, 569 Japan \\ Malcolm Bersohn \\ Chemistry Department, University of Toronto, Toronto Canada \\ M5S 1 AI
}

\begin{abstract}
Some synthetic routes proposed by our noninteractive organic synthesis computer program, SYNSUP-MB, are presented and the program is briefiy described. The input data to this program conveys the structure of the goal molecule, the maximum number of steps acceptable in the synthesis, the various structural requirements for an acceptable starting material or, optionally, a specific required starting material, reaction conditions which are for economic reasons unacceptable, whether or not any resolutions are allowed, etc. The output of the program consists of proposed routes. If no routes satisfying the program user's requirements are found then the program reports several pathways which come closest to satisfying the user-specified requirements.
\end{abstract}

\section{INTRODUCTION AND DISCUSSION}

Our synthesis planning program(ref. 1) has been under development by us since 1984. It performs extensive development of a synthetic decision tree at a rate, two or three reactions per second on our current hardware, which a chemist could not try to keep up with. In searching for synthetic routes, decisions must be made about the feasibility of each step in light of the selective reactivity necessary or the stereochemistry required or the effect of interfering groups. In our system these decisions are all made by the program at run time, without consulting with a chemist. The program is being developed with the guiding principle that the time to input chemical judgement and rules is while the program is being written, not while it is running. Because there are not enough reactions in the program it cannot propose a satisfactory solution for most difficult problems. Where the necessary reactions are present, the present version of the program does present plausible solutions, a few of which are presented below.

In synthesis planning, a chemist explores only a handful of routes but not all the steps of these conjectured routes need to have a remembered literature precedent. The chemist can look up the precedent in the library and use the procedure if it exists or else try to invent novel techniques to accomplish the transformation. Our present computer program, on the other hand, explores tens of thousands, sometimes even hundreds of thousands of routes. Since our program has no access to a library, every step of these routes must have a literature precedent stored inside of the program. Thus the chemist can be much more versatile but the program is less likely to overlook a route that can be accomplished entirely by well known chemistry. 
The time required to find a route varies from minutes to days depending on the difficulty of the problem. The number of syntheses proposed also depends greatly on the stringency of the demands for the synthesis. Depending on the user's stipulations the number of routes proposed varies from zero to hundreds. There are only a little over 2000 reactions in the program. This falls far short of containing the full power of synthetic organic chemistry.

In order to partly overcome the deficiencies of the program as a reasoning system, we have recently incorporated some ability to propose routes that contain suggested reactions that are not documented internally in the program but which are analogous to reactions which are documented there. This facility is activated only if the user includes a command to do so in the data input to the program.

\section{REFERENCES}

1. M.Takahashi, I.Dogane,M.Yoshida,H. Yamachika,T.Takabatake and M. Bersohn, J. Chem. Inf and Comp. Sci. (1990) in press.

2. M. Makosza and J.Winiarski,J.org.Chem. 45,1534(1980).

3. H.Pervez,I.Rees and C.J.Suckling.J. Chem. Soc. Chem. Commun., 512(1985).

4. Yu-shia Cheng, Wen-1iang Liu and Shu-hsia Chen, Synthesis, 223(1980).

5. G. Erker and A.A.H. van der Zeijden. Angew. Chim. Internat. Ed.,592 (1990).

6. G.Piancatelli and A. Scettri,Synthesis,116(1977).

7. G.Piancatelli, A. Scettri, and S. Barbadoro, Tetrahedron Lett., 3555 (1976).

\section{APPENDIX}

\section{SOME SAMPLE ROUTES PROPOSED BY THE PROGRAM}

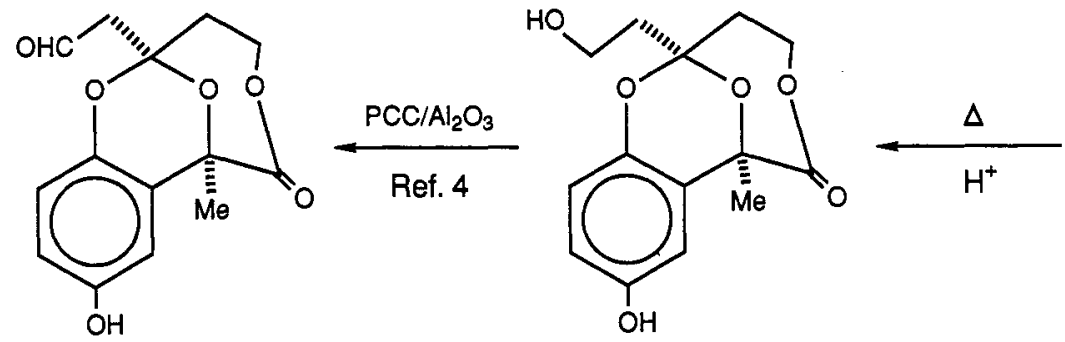<smiles>COC(=O)[C@@]1(C)OC(CCO)(CCO)Oc2ccc(O)cc2[C@]1(C)C(=O)OCC(=O)CO</smiles> 
II<smiles>C=CCC1=C(C)C(O)CC1=O</smiles><smiles>C=CCC1C(=O)C=CC1(C)O</smiles><smiles>C=CCC(O)c1ccc(C)o1</smiles><smiles>Cl[Mg]Cl</smiles><smiles>Cc1ccc(C=O)o1</smiles><smiles>Cc1ccco1</smiles>

III<smiles>CC(C(=O)O)c1ccc2oc(-c3ccc(Cl)cc3)nc2c1</smiles><smiles>CC(C)c1ccc2oc(-c3ccc(Cl)cc3)nc2c1</smiles><smiles>CC(C#N)c1ccc(O)c(N)c1</smiles><smiles>CC(C#N)c1ccc(O)c([N+](=O)[O-])c1</smiles><smiles>CC(C#N)c1ccc(O)cc1</smiles><smiles>CC1CCCCC1</smiles><smiles>CC(Cl)c1ccc(O)cc1</smiles><smiles>[Se][Os]</smiles><smiles>CC(O)c1ccc(O)cc1</smiles><smiles></smiles><smiles>CC(=O)c1ccc(O)cc1</smiles><smiles>CC(=O)Oc1ccccc1</smiles>

IV

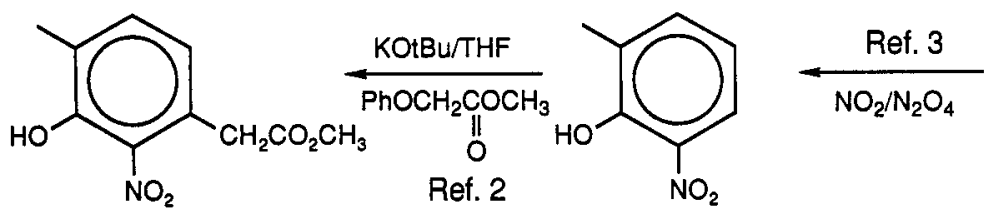<smiles>Cc1ccccc1O</smiles> 